\title{
A Pilgrimage to the Disneyland of Faith
}

Justin Crowe, Williams College

Susan McWilliams, Pomona College

Sean Beienburg, Princeton University

\section{ABSTRACT As part of a course considering "American Democracy in Theory and Practice,"} we took 36 students to Rick Warren's Saddleback Church in Lake Forest, California. During that visit, students observed a community that seeks self-sufficiency and yet proves to be simultaneously responsive to and reflective of American democracy more broadly. Specifically, in a few short hours, they were able to see the virtues of civic association, the difficulty of respecting individualism in large-scale polities, the influence of regional identity, and the two-way interaction between politics and culture-all themes that featured prominently in our course. We offer this reflection to suggest the pedagogical benefits of showing the tensions of American politics in action and to encourage colleagues to consider integrating similar ventures into their own courses.

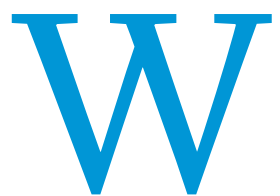

hat happens when a Jewish-raised atheist and an unbaptized Presbyterian who married a Quaker visit an evangelical megachurch? This question is not the beginning of a riddle or a joke, but the one we faced when taking our team-taught course on a field trip to Saddleback Church in Lake Forest, California. Prompted by Rick Warren's invocation at President Barack Obama's inauguration just a few weeks earlier, our proximity to Saddleback's main campus in Orange County, and the belief that it might be valuable for our students-a purportedly irreligious bunch-to culminate our study of religion in American democracy by visiting a real-life religious institution, we asked our 36 Pomona College students to wake up early and devote the better part of a Sunday to megachurch evangelicalism. We had no particular curricular agenda-students had read a few articles on evangelicalism but nothing on Warren or Saddleback specifically-and had not planned to debrief the trip formally upon our return.

Our students, however, responded intensely, drawing independent connections between the trip and the course at large. Our subsequent conversations with them compelled us to consider the ways in which this visit had been far more relevant to our "American Democracy in Theory and Practice" course than we had antici-

Justin Crowe is an assistant professor of political science at Williams College. His research interests include the Supreme Court, American political and constitutional development, and American political culture. He previously taught at Pomona College. He can be reached at jec3@williams.edu.

Susan McWilliams is an assistant professor of politics at Pomona College. Her research interests include American political thought, history of political thought, and politics and literature. She can be reached at susan.mcwilliams@pomona.edu.

Sean Beienburg is a graduate student in politics at Princeton University. His research interests include constitutional law, American political thought, and American political development. He was previously a Mellon Post-Baccalaureate Fellow at Pomona College. He can be reached at sbeienbu@princeton.edu. pated. We were also surprised to learn that we were the first college class ever to visit Saddleback. According to the pastors with whom we spoke, Saddleback has been visited by many spiritual groups from around the world but never by a group of political science students.

Because this visit turned out to be such a valuable and apparently unprecedented experience, we have used our students' words to organize our own thinking about Saddleback in terms of political science research and teaching. ${ }^{1}$ We offer these lessons not to suggest that every megachurch (or every religious institution, more generally) will display identical characteristics but, rather, in the hope that our colleagues might consider integrating similar ventures into their own American politics courses. Given that our students were far from unanimous about the respective virtues and vices of Saddleback, we leave aside normative judgments and instead focus on the pedagogical contributions of the visit to our students' understanding of American democracy.

\section{1. "SADDLEBACK SEEMED LESS LIKE A CHURCH THAN A CLUB."}

Famously, Alexis de Tocqueville saw religious institutions as sites of civic association. All of our students were familiar with this teaching, ${ }^{2}$ but most still marveled at the extent to which Saddleback was not merely a place to worship. "Even though the service is an important part of the church, there was so much more than the actual service," said one. "It was really a center for Christian life, with places for kids to go and skateboard." Even more than the myriad mega-malls in surrounding Orange County, Saddleback creates the impression of one-stop shopping: there is a worship center for parents, an early childhood education center, and a middle and high school center called the Refinery, as well as a series of cafes and outdoor activities. It is easy to imagine spending a full day, or many full days, on the campus. More broadly, 
Saddleback's programs include a network of more than 3,80o local small-group gatherings in approximately one hundred southern California cities. It would be almost impossible to visit Saddleback and miss the extent to which the megachurch experience is about more than the (many) two-hour services every weekend, facilitating association on terms which would impress any social capital theorist.

In fact, the two pastors who met with our students invoked Robert Putnam and his current research on religion. They raised this subject unprompted, in the context of explaining Saddleback's commitment to acting as a cultural center. In doing so, they made it clear that Saddleback's broad associational mission is intentional, not merely a byproduct of its religious message. "We meet people where they are," said one, arguing that "social networks" are central to a fulfilling life. Many of our students were astonished that these pastors were familiar with material that they knew from politics classes. ${ }^{3}$ They all noticed that the pastors referred to Putnam as "our good friend Bob."

Quite a few of our students, including some who express doubt about all forms of organized religion, saw the appeal of Saddleback merely in its associational role. "I saw why people would want to be in a community like that," said one student. As their professors, we were glad to see the lessons of thinkers like Tocqueville, Putnam, Robert Bellah, and Theda Skocpol-all of whom appear on the course syllabus-materialize so clearly in practice.

\section{2. "SADDLEBACK WAS LIKE TAKING A CLASS AT A UC."}

Coming from an institution of under 1,500, in which class enrollments are routinely under fifteen and almost always under forty, nearly all our students felt overwhelmed by a religious service catering to more individuals than their entire college. Indeed, they told us that in many ways, the social organization and governance of Saddleback was dramatically unlike what they were familiar with at Pomona and akin to something that their friends experienced at campuses of the University of California system. Although this observation did not particularly surprise us-Saddleback is, after all, a megachurch-the scale of the place did usefully draw our students' attention to the challenges of governance in large institutions.

Above all, our students were struck by the realization that democracy becomes noticeably more difficult when more individuals are involved. Indeed, a close look at Saddleback suggests that Rousseau's observation that "the larger the state becomes, the more liberty decreases" $(1994,93)$ applies even in nominally Protestant religious communities, which we traditionally think of as "bottom-up" in orientation. For example, although one of the first things we heard from Saddleback's high school pastor at the start of the 9 AM service was that the church was "taking a poll"complete with pencils and a "ballot"-about what types of activities and groups the worshippers would like to see, we also heard other pastors emphasize that Saddleback is not essentially democratic. As one remarked, "We don't hold votes on what color the buildings should be." This managerial posture, with its emphasis on "top-down" decision making in the service of efficiency and expediency, was evident in more than simply superficial realms. From the existence of satellite campuses in Irvine, Corona, and San Clemente designed to alleviate overattendance in Lake Forest to the three-tiered hierarchy of pastoral ranks-directors on the pastoral track, licensed pastors, and ordained pastors-to the synchronization of the timing of services embodying different worship styles-"Praise" (gospel) and "Overdrive" (Christian rock)—on the campus simultaneously, Saddleback is a model of Weberian bureaucracy.

Even something as central as Rick Warren's sermon itself, which was delivered via videotape that morning because the leader was feeling ill, resembled a modified PowerPoint presentation, with each worshipper being issued a notecard containing not only scriptural citations but also blank lines. Many of our students imagined that these lines might be for individual interpretation and were therefore surprised when Warren-and the six giant television screens in the worship center-instructed the attendees regarding the exact words that should appear on the notecards, which were conveniently pre-punched with three holes to encourage worshippers to save and serially organize the sermons at home. "Historically," one student observed, "Protestantism has emphasized individual reading and interpretation of scripture, but Rick Warren doesn't seem to leave much room for that in his service."

Some of our most astute students recognized the inherent tension between Saddleback's commitment to individual and personal rediscovery, on the one hand, and its logistical need for more centralized government, on the other. This observation allowed us to pursue more general discussions in the classroom about the tensions inherent in American constitutional democracy and to foreshadow future inquiries about the nature and challenges of representation in American politics.

\section{3. "IT FELT LIKE ANOTHER ATTRACTION IN SOUTHERN CALIFORNIA.”}

Popular culture, in the form of movies like Jesus Camp and Saved, tends to portray evangelicals as living in a world apart from mainstream American life and certainly from life on the left coast. As a result, many of our students were shocked to see how bound up Saddleback Church is in regional, southern California culture. Most memorably, the pastors speaking with our students referred to Saddleback, with great enthusiasm, as a "Disneyland of faith." In fact, they told us, Disney "Imagineers" had visited the campus to offer advice about landscaping and architectural design. (Some of our students independently speculated that Saddleback's tram service from the parking lots to the worship center operated on the Disneyland model.) For the pastors, Disney's participation in the design of Saddleback was part of an attempt to make individuals feel more at home there, which of course has the effect of making Saddleback feel almost exactly like everything that surrounds it.

For example, Saddleback's newest building complex has been LEED certified, a recognition for sustainable design that was familiar to our students, because Pomona, like many other southern California institutions, places great emphasis on the appearance of energy conservation. (Interestingly enough, the young-person Refinery has architectural features that are identical to Pomona's newest residence halls, a fact noticed by a number of our students, who also called the building "a nicer version of our campus center.") Clearly, Saddleback reflects rather than resists an awareness of the environmental problems that particularly plague the American Southwest. Our students left the campus with a vision of evangelicalism that is not removed from the region but in fact enmeshed within it.

The extent to which southern California permeates all that Saddleback does is evident even in the realm of doctrine. Many of our students said they had not expected Warren's sermon to sound so familiar. But even for those students who had never attended a 
religious service, it did sound familiar, largely because Warren relies heavily on the self-help language so prevalent in the region (and perhaps the nation at large). "It just didn't seem that different than watching Dr. Phil," one student observed. "It felt like a psychology workshop with a little Jesus thrown in," said another. Only a few students thought differently. After reading a Saddleback publication for children, one remarked, "I thought the whole religious aspect seemed really watered down and benign until I saw how specific and absolute the beliefs were."

For the purposes of teaching, the California character of Saddleback allowed us to develop a series of important points about American politics. Most obviously, being able to identify Saddleback as a locally-rooted institution makes clear the extent to which regional distinctions and identities are not moot in twenty-firstcentury American life-a topic that had already been slated for discussion in a unit on representation. More broadly, this observation lends itself to the conclusion that, despite popular perceptions, religious and secular life in America can never be fully separated and are, in fact, intertwined on many levels with each other.

\section{4. "IT'S TRICKLE-DOWN CHRISTIANITY."}

In perhaps the most trenchant observation of the day, one Saddleback pastor remarked to us that "politics is downstream from culture." This statement prefaced his claim that the leaders of Saddleback do not consider their work to be political-and certainly not politically conservative. ${ }^{4}$ In fact, the aforementioned Saddleback tenet that "we meet people where they are" goes along with an avowed distance from taking partisan or divisive political stands. Far from viewing themselves as an extension of any particular political party, Saddleback staff instead see their mission as creating a culture that will itself shape the contours of political debate further down the road. They argue that most issues are decided by the culture at large well before they occupy a prominent place on the political agenda. Saddleback, they said, is part of that prior, pre-political cultural conversation.

Perhaps this outlook explains in part why so many of Saddleback's buildings and practices resemble those from the realms of popular sports and entertainment-the great cultural centers of contemporary American life. "Observing the physical set-up of the campus-the children and teen building especially-[it] struck me as subtly religious," one student said, "with a primary emphasis on pop entertainment." On the surface, Saddleback certainly does seem more benignly cultural than explicitly political.

Still, many of our students noticed the extent to which the Saddleback pastors recognize that their public image and reputation directly influence their ability to pass their spiritual message downstream. "They realize that what they are doing ... is being watched by the outside world," said one student. Two conversations in particular-one in which the pastors began a tour of Saddleback's child-care facilities by emphasizing that there were no places where an adult could be alone with a child long enough to harm him or her, and another in which the pastors downplayed
Warren's support for Proposition 8-suggest an acute awareness of public perception.

This sensitivity, as our students observed, offers an interesting complication to the notion that religion is part of a culture that is "upstream" from politics. The pastors' firm insistence on disclaiming political conservatism and their frequent, unprovoked invocations of respect for pluralism and personal choice suggest an understanding that religious institutions always operate within, and not prior to, a political framework in which appearances matter a great deal. Politics may be downstream from culture, but that does not mean there are no eddies in which the current reverses course and-as so many of our course readings emphasized-the secular influences the sacred.

\section{CONCLUSION}

The fascinating and most pedagogically useful feature of Saddleback and large religious institutions in general is their attempt to create a community that is almost self-sufficient and yet simultaneously responsive to and reflective of broader trends in American democracy. The megachurch, that is, exists as a stage on which many of the central features of American politics can play out in a particularly dramatic form.

Not recognizing this reality, we first decided to take our class to Saddleback in the belief that megachurch evangelicalism is a prevalent force-and Saddleback a powerful player-in American political life. In other words, we went as a kind of "cultural pilgrimage"-just because it was there, just because we could. As we indicate here, however, we got a lot more than we bargained for-above all, the opportunity for our students to see the lessons of political science at work and the dynamics of American democracy not only in theory and practice but also in action.

\section{NOTES}

The authors would like to thank Pastors David Chrzan and Steve Gladen of Saddleback Church for their time and hospitality during our visit, Pomona College for its financial support in making our visit to Saddleback possible through a Wig Curriculum Development Grant, and, most of all, our students for their contributions to and enthusiasm about this article.

1. In creating this overview, we have left out a range of other reactions, including the realizations that evangelical beliefs were not as "simplistic and homogenous" as some students had previously thought and that Saddleback worshippers were not "crazy Jesus freaks" but "ordinary girls who dressed fashionably and had nose piercings."

2. Indeed, Tocqueville's Democracy in America is the only assigned book in our course, and by the end of the semester, students have read a substantial portion of it.

3. Our syllabus includes four pieces by Putnam himself: "The Strange Disappearance of Civic America," "Bowling Together," "E Pluribus Unum," and “Toward an Agenda for Social Capitalists" (from Bowling Alone).

4. Similarly, Warren's sermon began with an explicit disavowal of theocracy. "It has nothing to do with government," he said. "We're not trying to set up God's kingdom as a physical ... political, or institutional entity on the earth."

\section{REF EREN C E}

Rousseau, Jean Jacques. 1994. The Social Contract, trans. Christopher Betts. Oxford: Oxford University Press. 


\section{American Political Science Association}

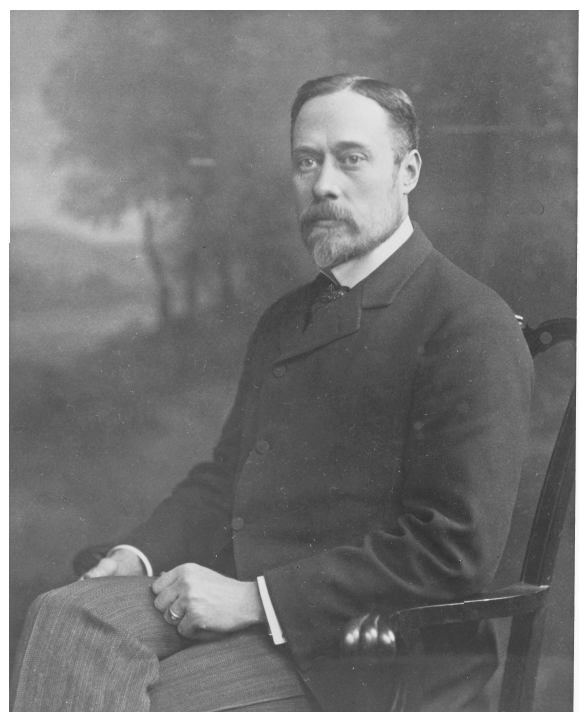

\section{Frank J. Goodnow Award for Distinguished Service}

The Frank J. Goodnow Award honors the contributions of individuals to the development of the political science profession and the building of the American Political Science Association. Frank J. Goodnow, APSA's first president and former president of Johns Hopkins University, exemplified the public service and volunteerism that this award recognizes. Goodnow was the first of many who voluntarily contributed an extraordinary amount of time, energy, and attention building our dynamic and learned profession.

The APSA Development Committee is accepting nominations, including self-nominations, for the 2010 Goodnow Award, to be presented Thursday, September 2, 2010, at APSA's 106th Annual Meeting in Washington, DC.

PREVIOUS RECIPIENTS OF THE FRANK J. GOODNOW AWARD

- Pendleton Herring

- Jewel Prestage

- Betty Glad

- Catherine E. Rudder

- Max Kampelman

- Gabriel Almond

- Samuel Patterson

- Frank J. Sorauf

- Eugene Eidenberg

- Doris Graber

- Austin Ranney

- Jean Bethke Elshtain

- Roberta Sigel
- Malcolm Jewell

- F. Chris Garcia

- Fred Greenstein

- Walter Beach

- Thomas Mann

- Gerhard Loewenberg

- Charles O. Jones

- Warren Miller

- Richard Fenno

- Dianne Pinderhughes

- Dale Rogers Marshall

- Nelson Polsby

- M. Margaret Conway
- Michael Preston

- Jack W. Peltason

- Paul Allen Beck

- Jennifer Hochschild

- John A. Garcia

- Norman J. Ornstein

- Kay Lehman Scholozman

- Paula D. McClain

- Frank P. Scioli

- Lee Sigelman

- Judith H. Stiehm

- Paul Sniderman

- Kenneth Janda

\section{NOMINATIONS}

Deadline: Monday, May 31, 2010

Please send a letter of nomination and one copy of the nominee's curriculum vitae to:

2010 Frank J. Goodnow Award American Political Science Association 1527 New Hampshire Avenue, NW

Washington, DC 20036-1206 